\title{
THE ANTI-COMPETITIVE ASPECTS OF TRADE NAME PROTEC- TION AND THE POLICY AGAINST CONSUMER DECEPTION I
}

In an unfair competition suit to protect a trade name, 1 the question to be adjudicated is whether or not one party will be permitted to exclude another from using a particular name. Since the question concerns the right to prevent another from using a certain name, it is perhaps natural that arguments against protection often use the emotive word "monopoly." The force of this term has been resorted to in efforts to restrict the ambit of protection in cases where the second user of a name is not directly competing in a common market. The recent decision by the Second Circuit in Lincoln Restaurant Corp. $v$. Wolfies Restaurant Inc. ${ }^{2}$ raises this controversial issue once again and resolves

1 The term "trade name" will be used herein to mean a name used to desigmate a particular business establishment. Such firm names, identifying the seller rather than his goods, are not registrable under the Lanham Act. 15 U.S.C. $\$ 1127$ (1958). Concerning technical and nontechnical trade-marks and names, see 3 Callmans, UNFAIR Competrtion AND TRADE-MARKS $\$ 66.1$ (2d ed. 1950). The present comment is intended to analyze the anticompetitive aspects of trade symbol protection. ("Trade symbols" will be used to include both trade-marks and trade names.) However, for convenience the textual discussion will be limited to trade name cases.

It should be noted that trade-marks often "serve the dual function of identifying both firm and product and so qualify as both trade-mark and trade name." Developments in the Law-Trade-Marks and Unfair Competition, 68 HARv. L. REv. 814, 822 (1955). It is frequently observed that the law of trade-marks is "but a part of the broader law of unfair competition...." United Drug Co. v. Rectanus Co., 248 U.S. 90, 97 (6th Cir. 1918); Hanover Star Co. v. Allen \& Wheeler Co., 208 Fed. 513, 518 (7th Cir. 1918). See also Alaska Sales \& Service, Inc. v. Rutledge, 128 F. Supp. 1, 2 (1955); Insect-O-Lite Co. v. Hagemeyer, 151 F. Supp. 829, 832 (1957). An examination of cases such as those cited infra notes 3 and 16 shows that the courts apply the same basic rules to trade-marks and trade names and that in judicial opinions the combined actions for trade-mark infringement and unfair competition become indistinguishable.

Some controversy exists as to the scope of protection afforded by Section $32(1)$ of the Lanham Act. 15 U.S.C. \$1114(1) (1958). In S. C. Johnson \& Son, Inc. v. Johnson, 175 F.2d 176 (2d Cir. 1949), Judge Learned Hand suggested that section 32(1) be interpreted as codifying the law of unfair competition as it existed in 1946. Judge Clark, dissentins, was inclined to interpret the section, as well as the existing law of unfair competition, as approving broader protection than suggested by Judge Hand. The controversy has not been clearly resolved. See, e.g., the problem as treated in Hyde Park Clothes, Inc. v. Hyde Park Fashions, Inc., 204 F.2d 233 (2d Cir. 1953); Browne-Vintners Co. v. National D. \& C. Corp., 151 F. Supp. 595, 603 (S.D.N.Y. 1957). However, the above mentioned tendency of courts to treat claims of trade-mark infringement and unfair competition as identical lends support to Judge Clark's view favoring broader protection under section 32(1). See Developments in the Law-Trade-Marks and Unfair Competition, 68 HARv. L. REv. 814, 849 (1955) (reasonably suggesting that the Lanham Act section can be interpreted to include the confusion of sponsorship doctrine - a doctrine discussed infra note 16 and accompanying text). But even if the protection of the Lanham Act is not fully coextensive with that provided by present doctrines of unfair competition, regardless of whether trade-marks or trade names are being discussed, the problems of analyzing anti-monopoly arguments remain the same.

2291 F.2d 302 (2d Cir.), cert. denied, 368 U.S. 889 (1961). 
it, says a dissenting justice, by granting a permanent "non-statutory monopoly" to the complainants. ${ }^{3}$ Since anti-monopoly thought may shape the law in this field, it is important to consider the basis for trade name protection, the meaning of "monopoly" as it has been applied, and the extent to which the policy underlying monopoly arguments should influence decisions.

The Wolfies case illustrates a recurrent type of factual situation. 4 The plaintiffs operated two restaurants and sandwich shops called "Wolfies" in Miami Beach, Florida. The defendant, with knowledge of the plaintiffs' prior use, opened a restaurant called "Wolfies" in Brooklyn, New York. The evidence revealed that the plaintiffs' Florida restaurants were particularly well known in Brooklyn. 5 The menu used by the defendant closely resembled the plaintiffs' in color and format and offered "Wolfie's Floridian Style" delicacies. These facts established a deliberate attempt by the defendant to encourage the belief that this was a "Brooklyn branch of plaintiff's enterprises." 6 The majority of the court held that such practices constituted "palming-off"' and affirmed the decree for an injunction restraining the defendant from using the name "Wolfies." Moore, dissenting, charged that the decision gave a Florida restaurateur, who had chosen a "not too unique nickname," "a non-statutory monopoly through the medium of the "unfair competition doctrine." "8

II

Before examining anti-monopoly arguments, it is instructive to consider first the basis and operation of the judicially accredited theory of trade name protection. This approach coincides with the course of historical development, for a doctrine of trade name protection was well established before monopoly arguments were advanced.

3 Id at 304 (Moore, J.). Judge Frank endowed the Second Circuit with a strong undercurrent of monopoly-resisting in trade name cases. Sec his opinions in: Triangle Publications, Inc. v. Rohrlich, 167 F.2d 969, 974 (2d Cir. 1948) (dissenting); La Touraine Coffee Co. v. Lorraine Coffee Co., 157 F.2d 115, 119 (2d Cir. 1946) (dissenting); Standard Brands, Inc. v. Smidler, 151 F.2d 34, 37 (2d Cir. 1945) (concurring); Eastern Wine Corp. v. WinslowWarren, Ltd., 137 F.2d 955 (2d Cir. 1943).

4 See, e.g., cases involving restaurant names: Ambascador East, Inc. v. Orsatti, Inc., 257 F.2d 79 (3d Cir. 1958); Stork Restaurant, Inc. v. Sahati, 166 F.2d 348 (9th Cir. 1948); Nagrom Corp. v. Cock'N Bull, Inc., 149 F. Supp. 217 (D.D.C. 1957); Ambassador East, Inc. v. Shelton Corners, Inc., 120 F. Supp. 551 (S.D.N.Y. 1954); Stork Restaurant, Inc. v. Marcus, 36 F. Supp. 90 (E.D. Pa. 1949); Brass Rail Inc. v. Ye Brass Rail of Mass, Inc., 43 F. Supp. 671 (D. Mass. 1938); Vaudable v. Montmartre, Inc., 20 Misc. 2d 757, 193 N.Y.S.2d 332 (Sup. Ct. 1959); James Burrough, Ltd.v.Ferrara, 8 Misc. 2d 819, 169 N.Y.S.2d 93 (Sup. Ct. 1957); Maison Prunier v. Prumier's Restaurant \& Cafe, Inc., 159 Misc. 551, 288 N.Y.S. 529 (Sup. Ct. 1936).

5 The president of one of the plaintiffs textified that, at his Miami Beach restaurant, 50 to 60 per cent of the daily patronage was from Brooktyn. 291 F.2d at 303.

6 Ibid.

TThe decision expreasly rests on the "palming-off" doctrine, or more accurately, on an acoepted extension of that doctrine. See infra at 374.

- 291 F.2d at 304-05. 
The law of trade names has been predicated on the protection of the public from deception. 9 Or, to phrase it differently, the primary aim has been to safeguard the identifying or informing function of trade symbols. ${ }^{10}$ Pointing this out does not, however, mean that judicial action has not also stemmed from a desire to protect the good will associated with a businessman's trade name. Yet, if the desire to protect symbolized good will had become the basic consideration shaping the law, the scope of protection would probably be broader. The limited protection is best explained when the policy of preventing consumer deception is accepted as controlling and defining the scope of protection. ${ }^{11}$ The courts protect the good will associated with a complainant's trade name only insofar as is required by the policy against consumer deception. Of course, a complainant seeking relief is often more interested in protecting the persuasive value, or magic selling power, of his name than in merely preserving its identifying function.

The first rationale of legal action was to prevent one merchant, by the use of the same or similar trade symbols, from "passing-off" or "palming-off" his goods as those of another. 12 This simple rule expanded to meet the needs of a more complex commercial society. The doctrine of confusion of source developed to deal with cases in which, despite the lack of market competition between the parties, the use of similar symbols created the false impression that the goods emanated from the same source. In the famous case of Yale Elec. Corp. ". Robertson 13 the court held that the maker of "Yale" locks was entitled to injunctive relief against the use of its mark on flashlights and batteries although it made neither flashlights nor batteries. Judge Leaned Hand declared that "it has come to be recognized that, unless the borrower's use is so foreign to the owner's as to insure against any identification of the two, it is unlawful." 14 Such an expansion of the "passing-off" notion was logical, for, despite the apparent contradiction of finding "unfair competition" without competition, the purpose remained the same: to prevent consumer deception.

Finally, from the confusion of source doctrine emerged the modern doc-

9 The wrong to be remedied has often been viewed as a form of commercial fraud. The Restatement of Torts treats trade names and marks as one topic in a chapter also dealing with "the conditions of liability of one who fraudulently markets goods as those of another or... who imitates the physical appearance of goods marketed by anotber." 3 RESTATEMENT, TORTS 535, 541 (1938).

${ }^{10}$ See Pattishall, Trade-Marks and the Monopoly Phobia, 50 Mict. L. REv. 967 (1952).

11 Advocates of more extensive trade name protection sometimes conveniently assume that the established judicial doctrine is primarily intended to protect the reputation and good will of the plaintiff. See, e.g., Note, The Monopoly Concept of Trade-Marks and Trade-Names and the "Free Ride" Theory of Unfair Competition, 17 GEO. WAst. L. REV. 112 (1948).

123 RESTATEMENT, TORTS $\$ 717$, comment $a$ at 564 (1938).

1326 F.2d 972 (2d Cir. 1928).

14 Id. at 974. 
trine of confusion of sponsorship. Under this doctrine the appropriator of a trade symbol will be enjoined if his acts are likely to create the impression among ordinary customers 15 that his business or product is associated with or endorsed by the senior user. ${ }^{16}$ Although the court in the Wolfies case concluded that the defendant's practices amounted to "palming-off," 17 the case is more accurately described as involving confusion of sponsorship. The analogy to "palming-off" is, however, both appropriate and suggestive: for the analogy indicates the logical expansion of the original rule into the more broadly formulated likelihood of confusion test.18

The test applied is objective, and, therefore, injunctive relief can be obtained regardless of the appropriator's knowledge or intent. 19 But the purpose,

15 The touchstone is the "ordinary purchaser" acting under the normally prevalent conditions in the trade and giving the attention usually given to the purchase of such goods or services. He is essentially the familiar "reasonably prudent man." 3 CalLMasx, op. cit. supra note 1 , at $\$ 81.2$.

I6 See cases cited supra note 4. In a number of cases the defendant's conduct created the likelihood of a false impression of endorsement or recommendation by the plaintiff. Triangle Publications, Inc. v. Rohrlich, 167 F.2d 969 (2d Cir. 1948) (publishers of a girls fashion magazine called "Seventeen" obtained an injunction prohibiting the unauthorized use of the label "Miss Seventeen" on girdles); Hanson v. Triangle Publications, Inc., 163 F.2d ?4 (8th Cir. 1947) (publishers of "Seventeen" obtained an injunction against the use of the name on dresses for girls); Esquire, Inc., v. Maira, 101 F. Supp. 398 (M.D. Pa. 1951) (publisher of "Esquire" fashion magazine for men obtained injunction against the use of the name "Esquire" on a men's clothing shop); Esquire, Inc. v. Esquire Bar, $37 \mathrm{~F}$. Supp. 875 (S.D. Fla. 1941); James Burrough, Ltd. v. Ferrara, 8 Misc. 2d 819, 169 N.Y.S.2d 93 (Sup. Ct. 1957) (injunctive relief granted to the distiller of "Beefeater" gin against the use of that name on a restaurant selling liquor).

The issue of likelihood of confusion is an issue of fact as to the probable reactions of ordinary customers. Q-Tips v. Johnson \& Johnson, 206 F.2d 144, 147 (3rd Cir. 1953). See also 3 RESTATEMENT, ToRTs $\$ 728$, comment $a$ (1938). The factual nature of the issue leaves some ambiguity in the law when new cases arise involving different markets and names, but in all cases granting relief, the courts have found some colorable evidence of confusing similarity. See, e.g., the controversial case of Tiffany \& Co. v. Tiffany Prod., Inc., 147 Misc. 679, 264 N.Y.S. 459 (Sup. Ct. 1932).

17 With reference to the defendant's conduct, the court concluded: "[W]e see no distinction between this and ordinary 'palming-off' in a products case." $291 \mathrm{~F} .2 \mathrm{~d}$ at 303.

18 See 3 Callmann, op. cit. supra note 1, at 1650-51; Note, 41 Corsell L. Q. 515, 517 (1956). Under each of the three doctrines, i.e., "palming-off," confusion of source and confusion of sponsorship, the applicable test is the likelihood of confusion.

19 "Where the necessary and probable tendency of the defendant's simulation or resemblance of the plaintiff's trade name is to mislead the public into believ ing that the defendant"s business is that of or connected with the plaintiff's, then neither actual confusion nor actual fraudulent intent need be shown, for the court is then concerned with the consequences of defendant's conduct and not the motive for them." Great Atl. \& Pac. Tea Co. v. Atlantic \& Pac. Trucking Corp., 51 N.J. Super. 412, 420, 144 A.2d 172, 176-77 (App. Div. 1958). 3 CalmunN, op. cit. supra note 1 , at $\$ 82.2(\mathrm{~b})(1)$.

In the Wolfies case, Judge Moore correctly observed that "intent is not controlling." 291 F.2d at 305. It is wrong, however, to suggest further, as he does, that the uniqueness of a trade name is the only factor that can bring a case within the confusion or "deception category." For other factors, see 3 RestateMENT, TORTS $\$ 729$ (1938). 
or bad faith, in choosing a particular name ${ }^{20}$ can be an important factor in determining whether there is a likelihood of confusion.21 The courts have been "quick to grant relief in cases of fraud or bad faith, even though the businesses of the litigants are not in competition." 22 A finding of bad faith plus an attempt to suggest the approval or recommendation of the prior user can be decisive even though the attempted suggestion is only slightly deceptive and appears almost humorously pathetic. ${ }^{23}$ The presence of such bad faith explains some decisions in which the actual likelihood of mistaken association would otherwise appear minimal.24

One other factor affecting the issue of confusing similarity merits special attention here because of its particular relevance to monopoly notions. The factor is the degree of distinctiveness of the trade name.25 An amorphous, but useful, distinction between "strong" and "weak" names prevails in the law. The strength of a name depends both upon its popularity and distinctiveness. 26 The courts have frequently declared that the stronger the name, the wider the ambit of protection, i.e., that the degree of strength affects the degree of exclusive appropriation permitted the originator. 27 Names which are common, personal,28 descriptive, or laudatory tend to be weak;29 whereas

20 A reasonable explanation for the defendant's choice of a similar name will offiset the normal inference that he chose it with intent to deceive. The defendant in the Wolfies case, however, "indulged in a series of fantastic explanations." 291 F.2d at 304 (Moore, J.). See 3 Callman, op. cit. sizpra note 1 , at $\$ 82.2(b)(2)$.

21 As the American Law Institute observed: "[If a person] adopts his designation with the intent of deriving benefit from the reputation of the trade-mark or trade name, his intent may be sufficient to justify the inference that there is confusing similarity. Since he was and is intimately concerned with the probable reaction in the market, his judgment manifested prior to the controversy is highly persuasive. His denial that his conduct was likely to achieve the result intended by him will ordinarily carry little weight." 3 RESTATEMENT, TORTS $\$ 729$, comment $b$ at 595 (1938). An analogous type of reasoning is common in other areas of the law. In antitrust law, "the most familiar example ... is the notion that proof of intent to produce unlawful effects upon the market will provide a sufficient basis for concluding that the effects in question actually took place." Bok, The Tampa Electric Case and the Problem of Exclusive Arrangements under the Clayton Act, 1961 SuP. CT. REv. 267, 297 n.94.

22 El Chico, Inc. v. El Chico Cafe, 214 F.2d 721, 725 (5th Cir. 1954). In New York it is a criminal offense, as well as a civil wrong, to use a confusingly similar trade name with the intention of deceiving the public. N.Y. PENAL LAw \$964.

${ }^{23}$ See Stork Restaurant, Inc. v. Sahati, 166 F.2d 348 (9th Cir. 1948); Stork Restaurant, Inc. v. Marcus, 36 F. Supp. 90 (E.D. Pa. 1941); Tiffany \& Co. v. Tiffany Prod., Inc., 147 Misc. 677, 264 N.Y.S. 459 (Sup. Ct. 1932).

24 See cases cited note 23 supra.

${ }^{25}$ See, e.g., Jewel Tea Co. v. Kraus, 187 F.2d 278, 282 (7th Cir. 1951); Sunbeam Lighting Co. v. Sunbeam Corp., 183 F.2d 969, 972 (9th Cir. 1950).

263 Callmann, op. cit. supra note 1 , at §82.1(1).

27 See note 25 supra.

28 Cases involving personal names are complicated by the feeling that one should have the "inherent right" to the use of his own name. Brooks Bros. v. Brooks Clothing of Calif., Ltd., 60 F. Supp. 442,449 (S.D. Cal. 1945). If the defendant chose a family name, despite 
names which are coined. fanciful, or arbitrary tend to be strong. A simple rationale underlies the broader protection afforded distinctive names: the more distinctive the name. the greater the probability that businesses using a similar designation will be regarded as connected with or approved by the prior user. -20

\section{III}

With the common law doctrine and its operation thus briefly outlined. the significance of monopoly notions may be examined. An analy sis should begin with a consideration of the meaning attached to the term "monopoly." for it has frequently been employed. without discrimination. in two different senses. First, "monopoly" can mean simply the exclusive right to, or exclusive possession of, something. 31 Second. the term may describe a market condition. Monopoly, in the economic sense. ordinarily means control over the supply32 in a given market.33 and consequently control over price. it The exclusive right and economic meanings are related. for an exclusise right may create market powers, yet each meaning has been used to suggest different reasons for deny-

the presence of confusing similarity, the courts are inclined to order the addition of a first name or prefix rather than grant the more drastic remedy of prohibiting the use of the name itedf. Lemer Stores Corp. Y. Lemer, 162 F.2d 160 (9th Cir. 194\%); Libby, Mf. Veill \& Libby v. Libby, 103 F. Supp. 968 (D. Mass. 1952); J. A. Dougherty's Sons, Inc. v. Dougherty, 36 F. Supp. 149 (E.D. Pa. 1940), 39 MICH. L. REv. 1047 (1941).

Conversely, the drastic remedy is more likely where the choice of a confusingly similar name cannot be explained. Brooks Bros. $v$. Brooks Clothing of Calif., supra.

20 The popularity of a name and its association with a certain source or sponsor vill lend strength to a non-distinctive name. In Skil Corp. v. Barnet, 337 Mass. 485, 494, 150 N.E.2d 551, 557 (1958), the court said: "Although Skil as a mark for namel is not as easy to protect as a more unique one, its secondary meaning can be protected to an appropriately limited extent."

303 RestateMe.NT, TorTs $\S 731$, comment $e$ (1938). But see Schechtet, The Rational Basis of Trademark Protection, 40 HARv. L. REV. 813, 831 (1927) w here the author relies upon the rule affording broader protection to distinctive names in order to buttress his argument "that the preservation of the uniqueness of a trademark should constitute the only rational basis for its protection...."

In considering the traditional nillingness to protect strong names, it should be noted that such names are ordinarily not initated except with intent to deceive.

31 See Webster's New Lternational Dictionary (2d ed. 1957 ).

32 Chamberin, The Theory of Mowopolistic Cohpetmitios 7 (7th ed. 1956); SamlelSON, ECONOMICs 456 (4th ed. 1958).

33 The term "monopoly" is meaningless without reference to the market controlled. For both the coconomist and the antitrust lanyer the definition of a market presents major diffculties. See notes 42-46 infra and accompanying text. On the problem of the "relevant market" in antitrust Law, see United States v. E. I. DuPont De Nemours \& Co., 351 U.S. 377 (1956).

34 "The essence of full monopoly porier resides in being the sole source of a product, so that the buyer must meet the seller's terms or go without. . . . All the factors and elements which constitute this idea are summed up by the convenient short-hand reference to monopoly power as power over price or power to exclude competitors." ATr'y Gex. NAt'L Comm. AVTITRLST REP. 318 (1955). 
ing trade name protection. Only when these two meanings are clearly distinguished can the validity of monopoly-based arguments be rationally assessed.

Insofar as "monopoly" merely designates an exclusive right, the term legitimately applies to one's house and automobile as well as to protected trade names. "Monopoly" is meaningless without reference to the subject-matter, the something, to be monopolized. In a number of cases, courts have employed the exclusive-right meaning with the implication that the something monopolized was the English language. For example, in one trade name case, the court declared that to grant protection "would be tantamount to a gift of exclusive ownership of the use of an English word."3s The dissent of Judge Moore ín the Wolfies case contains a rather obscure, undefined application of the term "monopoly," but his reasoning seems to depend in part upon the ideas that the something monopolized is the English language. Such reasoning may reflect an understandable reluctance to create privileges concerning the use of common words--words that seem to belong in the public domain. Perhaps connected with this reluctance is a vague feeling that, through advertising, a party should not be able to buy the privileged use of a common word. 36

But, regardless of any distaste for word "buying," it is submitted that the common law doctrine of trade name protection raises no significant danger of a language-monopoly. First, the exclusive rights to a name are quite limited. These rights do not extend beyond the commercial, denominative use of the words and the bounds of the likelihood of confusion doctrine. As has been indicated, the rights to common, descriptive, and laudatory words-i.e., to generally "weak" names-are particularly restricted. Furthermore, if a product name becomes generic, all claims to exclusive rights will be denied. Thus when it is found that a name such as "shredded wheat" has become the household name for a product, the law will allow others to adopt that name. ${ }^{37}$ This rule enables a newcomer to describe his product as it is described in the common language so that there will be an opportunity for competition. Second, an emphasis upon the rights to a specific name ignores the infinity of names remaining. ${ }^{38}$ If, for a moment, market conditions may be laid aside

35 Majestic Mfg. Co. v. Majestic Elec. Appliance Co., 79 F. Supp. 649, 651 (E.D. Ohio 1948). See also Sunbeam Lighting Co. v. Sunbeam Corp., 183 F.2d 969, 973 (9th Cir. 1950); California Fruit Growers Exch. v. Sunkist Baking Co., 166 F.2d 971, 974-75. (7th Cir. 1947).

36 See S. C. Johnson \& Son, Inc. v. Johnson, 116 F.2d 427, 429 (2d Cir. 1940). See also Note, 36 N.C.L. REv. 105, 109 (1957).

37 In Kellogg Co. v. National Biscuit Co., 305 U.S. 111, 116-17 (1938), the Supreme Court stated that, since "shredded wheat" was a generic term, "the original maker of the product acquired no exclusive right to use it. As Kellogg Company had the right to make the article, it had, also, the right to use the term by which the public knows it."

38 Some judicial statements have stressed the infinity of names freely available to a newcomer. Stork Restaurant, Inc. v. Sahati, 166 F.2d 348, 361 (9th Cir. 1948); Maison Prunier v. Prunier's Restaurant \& Cafe, Inc., 159 Misc. 551, 553, 288 N.Y.S. 529, 531 (Sup. Ct. 1930. 
and only the resources of the English language are considered, it seems obvious that no undue hardship arises from requiring that a party choose a name which is not confusingly similar. When the limitations on name-rights and the infinity of names remaining are noted, there appears to be no significant danger of depleting the available vocabulary. Indeed, one may reasonably sympathize with the feeling of Judge Clark, who once, when confronted with a language-monopoly argument, simply replied that, "a monopoly of the words 'La Touraine-Lorraine' for a coffee-bean hardly seems world shattering."39

The unfavorable connotation attached to "monopoly" derives from its economic meaning. Judge Frank, the most outspoken judicial exponent of an anti-monopoly policy in this field, generally used "monopoly" in an economic sense. 40 Resisting what he interpreted as an unwarranted extension of the common law rules, he said:

Without doubt, the judge-made trade-name doctrine or concept fosters monopolies and, generally speaking, the common-law tradition is inimical to monopolies (although opposition to monopoly when it takes the form of obsessive monopoly-phobia becomes absurd). Some writers, disturbed by the suggestion that judicially-protected trade-names are monopolies, protest that the judicial protection of trade-names rests on prevention of unfaimess between competitors, not on protection of monopoly. But, no matter by what doctrinal path the courts arrive at their results in this field, the judicial restraints of the defendants do yield plaintiff's monopolies. To the practical, social consequences of their decisions, the courts ought not shut their eyes. A concept is what it does. If a legal concept produces a monopoly, the concept, pragmatically, is a concept favoring monopoly.41

With regard to this demand for a realistic appraisal, it must be recognized that protected trade symbols do have monopolistic aspects. Trade symbols persuade as well as inform; by differentiating a product or business, they tend to lift it out of its general competitive class into a class of its own.42 Product homogeneity is usually considered a prerequisite for pure or perfect competition. ${ }^{43}$ The differentiation introduced by trade symbols may, therefore, result in market prices not wholly explicable by reliance upon models of pure or perfect competition. Professor Chamberlin emphasized the similarity: between patents and trade-marks: "Each makes a product unique in certain respects; this is its monopolistic aspect. Each leaves room for other commodities almost but not quite like it; this is its competitive aspect. The differences

39 LaTouraine Coffee Co. v. Lorraine Coffee Co.. 157 F.2d 115, 118 (2d Cir. 1946).

4 See cases cited note 3 supro.

41 Triangle Publications, Inc. v. Rohrlich, 167 F.2d 969, 982 (2d Cir. 1948).

42 See Borchardt, Are Trademarks an Antitrust Problem? 31 GEO. LJ. 245, 246 (1943).

43 Sayctelsos, op. cit. supra note 32, at 452-5S. 
between them are only in degree...."44 If attention thus focuses upon departures from the theoretical models of pure or perfect competition, it may seem logical to conclude that a protected trade symbol creates a separate, insulated market where price is independent of the price of similar goods or services that would otherwise be in the same market. 45 But a "market" should be defined as the sphere of competitive rivalry within which consumers can freely transfer their patronage from one supplier to another. ${ }^{46}$ This definition suggests that similar products or services, sold under different trade symbols, may be effective substitutes and hence within the same market. It is within such a market that the monopoly power of a name should be measured. In assessing the importance of the monopolistic effects of protected trade names, both legal writers and courts have tended to gloss over the difficult problems of determining the market and of measuring the market powers that are created.

A recognition of the monopoly implications of trade name law leads to the question of whether the protection afforded trade-marks and trade names raises antitrust problems. Although there has been some controversy, the better view is that the protection of a trade symbol per se does not create antitrust problems. ${ }^{47}$ The relevant market in which the power of a symbol is to be measured will include similar goods or services sold under different symbols and competing as effective substitutes. Antitrust law does apply, however, where a party has used its mark or name to implement a general anti-competitive scheme. 48 The opinion of the Supreme Court in the DuPont Cellophane case 49 lends support to the view that trade name protection raises no inherent antitrust problems. With specific reference to Professor Chamberlin's observations, the Court said:

Thus one can theorize that we have monopolistic competition in every nonstandardized commodity with each manufacturer having power over the price and production of his own product. ${ }^{50}$ However, this power that, let us say, automobile or soft-drink manufacturers have over their trademarked products is not the power that makes an illegal monopoly. Illegal power must be appraised in terms of the competitive market for the products. 51

44 Chamberlin, op. cit. supra note 32, at 62.

45 See $i d$. at 56-70.

46 See Att'y. Gen. Nat'l Comm. ANtitrust Rep. 322 (1955).

47 Oppenheim, Federal Antitrust Law: Cases and Comments 908-12 (2d ed. 1959). See generally Developments in the Law-Trade Marks and Unfair Competition, 68 HARv. L. REv. 814, 895-908 (1955). But cf. Borchardt, supra note 42; Timberg, Trade-Marks, Monopoly, and the Restraint of Competition, 14 LAW \& CONTEMP. ProB. 323 (1943).

48 See, e.g., United States v. General Elec. Co., 82 F. Supp. 753 (D.N.J. 1949). See generally Borchardt, supra note 47; Timberg, supra note 47.

49 United States v. E. I. DuPont De Nemours \& Co., 351 U.S. 377 (1956).

so The Court cited Chamberlin, Theory of Monopolistic Competition, ch. IV. 351 U.S. at 393 n. 20.

Si 351 U.S. at 393. 
Wis the differentivation andioned by the hw of unfair competition does not creare "itlegal monopolies" within the antitruet acts, opiniors differ as to whether or not the market effects of niame protection afford a sufficient reason for restricting the judicial trade name doctrine. Some commentators, fearing mosopolietic tendencies, approve protection under the confusion of source doctrine but apparently oppose the sponsorship doctrine with its broader scopes2 Oibers acoept the latter doctrine and further contend that trade name protection is essentially consonant with effective competition. 53

Significantly, the opponents of monopoly, while pointing to the economic effects of the judicial doctrine, usually request only a restriction of trade name protoction. With the notable exception of Professor Chamberlin, $s 4$ neither judges nor writers have advocated the abolition of all protection. Judge Frank, for example, simply challenged the desirability of extending protection to cases in which the defendant operated in a different fiekd of business.5s Similarly, Judge Moore in the Wolfies case merely objected to protection where the defendants, because of their geographical location, were not competing in the same market. In fact there is almost universal agreement that there should be no limitation of trade name protection where parties compete in the same region in the same class of goods or services. Yet this protection in the immediate market is precisely that most capable of conferring price immunities and market powers. Thus the economic argument is not advanced where prima facie it shonld be most persuasive. The explanation for this apparent inconsisteacy and for the position taken by the law would seem to be that the desire to prevent consumer deception has been controlling.

Preventing consumer deception is not simply a negative policy. Underlying

s2 See Brom, Adrertising and the Publie Ederest: Legal Protection of Trade Symbols, 57 YALE L. 1165 (1948); Timbars sisce note 47; Zlinkoff, Monopoly Versus Competition:

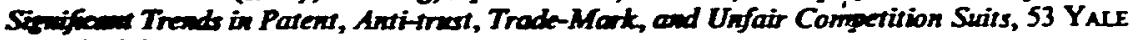
L.J. 514 (1944)

The opirions of Judge Frank are generally in accord with the views presented by the above cited writers. His opinion in Triangle Publications, inc. v. Rohrtich, 167 F.2d 969 (2d Cir. 1940), reveals a reluctance to accept the now judicilly accredited confusion of sponsorship doctine. Sec coses cited supra notes 3 \& 16.

53 See Note, 2n,ra note 11 ; Partishall, sqpra note 10. The first author stresses what may be called the "fruits of cormpetition" argument. The proposition sugested is that the good will of a buine is the "fruit of a froc coconomy" and that rules preserving such benefits augment competitive incentives. Appealing as the argument is, it should be noted that in granting "fruits" to cone party, the law may be crating martet controlling powers that will discourage the competivive incentive of others. The teat for competition stremed by the author is froedom $\alpha$ acoes to the market. In uning this teat, he implies that trade name protection has had no inificen monopolistic implications. But as another writer has inficated, in the tobacco inderry, where price competition is not keen, the differentintion promoted through brand nony tead to exclude potential competitors. See Murchison, Significance of the Ameriour Tebuces Company Cax, 26 N.C.L. Rev. 139, 163 (1948).

st Cun zunn, op. cit. spra note 32, at 270-74.

ss Sac cases cited sugra note 3. 
it is the idea-similar to that found in the law of contracts-that a consumer should act as a free, informed party. Since courts rule that imitation causing confusing similarity is a civil wrong, trade symbols provide a reasonably reliable indication of the quality to be expected from goods and services. In doing this, trade symbols help the consumer make a more informed, and hence freer choice. Professor Chamberlin recognized the basic need for some means of quality indication but nevertheless he argued in favor of "trade-mark infringement and 'unfair trading.' "s6 To replace the present law governing trade symbols, he suggested two alternative means of providing quality information. Either (1) the courts might follow a policy of permitting the imitation of a trade symbol only if the goods or services were identical in quality or (2) the legislature would abolish the protective rules by defining standards of quality by law. He conceded that the first alternative was "condemned by its impracticability," 57 presumably because of the difficulties and uncertainties attendant upon a distinction between what is and is not identical in quality. Despite Professor Chamberlin's suggestion to the contrary, the second alternative seems equally impracticable. Even if it is relatively easy to define quality standards for staple products, it is highly improbable that, with respect to other goods and services, legislators could establish meaningful standards with sufficiently fine gradations to make the consumer aware of the range and variety of qualities from which he may choose.

With the exception of Professor Chamberlin, there has been at least implicit approval of the controlling importance of the informing function of trade names. An acceptance of the policy against consumer deception justifies protection wherever there is a likelihood of confusion. As has been indicated, the confusion of sponsorship doctrine stems from the old "passing-off" concept and is but a logical extension of the same basic policy. The sponsorship doctrine may preserve powers created by protection within the immediate competitive market. However, the effect is indirect for this broader doctrine restricts non-competitors. It is submitted, therefore, that despite the monopolistic implications, to be consistent with their main objective, the courts should continue to apply the sponsorship doctrine within the limits of a reasonable likelihood of confusion.

\section{IV}

The main force of anti-monopoly argument has been directed at the socalled "dilution theory," a much discussed new departure in the law of trade marks and names. 58 Judge Frank once described Callmann-a protagonist of

56 CHAMBERLiN, op. cit. supra note 32 , at 270.

57 Id. at 273.

58 Frank I. Schechter initiated the American discussion of the new theory. Schechter, supra note 30. The history of the theory is too well known to require review, but for a 
the difution theory -as an "enthusiastic supporter of trade-name monopolies." 59 The advocates of this new theory desire a scope of protection beyond that provided by the confusion doctrine. Their main objective is to protect highly distinctive trade symbols from imitations causing a gradual erosion or dilution of the symbols' persuasive value or selling power.

It has been suggested that this theory "extends the owner's rights so far that he has a virtual monopoly on the commercial, denominative use of the words in the English language." 60 The term "monopoly" is used here in the exclusive-right sense with the familiar type of reference to a possible languagemonopoly. It is true that, if the dilution theory is applied as suggested by its advocates, it would provide unlimited protection against the commercial imitation of coined, fanciful, and-perhaps-"very strong" names. ${ }^{61}$ Although four states have adopted the theory by statute, 62 thus far the principal effect of these statutes has been to assure that courts tending to cling to the narrow "passing-off" concept will accept the confusion of sponsorship doctrine.63 No

sample of filution advocacy, see 3 Canukans, op. cit. supra note 1, at \$84.2; Derenberg The Frablem of Dilution and the Antidilution Statuas, 44 CAlIF. L. REV. 439 (1956).

For a sample of difution opposition, see Brown, supra note 52; Middleton, Some Reflectious on Dibution, 42 Tendevaler REP. 175 (1952).

The leading advocates of the dilution theory concede that no cases have turned on Dhution abone-3 Caumenn, op. cil.sugra note 1, at \$84.2; Derenberg, supra at 451. Houever, fos states have adopted the theory by statute: GA. CODE ANs. \$ร 106-15 (1956). ILL. Rev. Stat. ch. 140, $\$ 22$ (1959); Mass Gear. Laws ANN. ch 110, 8 7A (1954); N.Y. GeX; Bus. LAw \$ 368-3(3). The Mesochuests and New Yort statutes, which are ideatical. provide: "Likciinood of injury to business reputation or of dilution of the distinctive quality of 2 trade mame or trado-mart shall be a ground for injunctive relief in cases of trade-mark infingement or unfair competition, notwithstanding the absence of competition between the parties or the abeence of confusion as to the source of goods or services."

The Lanitam Act does not acoept the dihution doctrine as a basis for relief in trade-mark cance 15 US.C. $81114(1)$ (1958). See Avon Shoe Co. v. David Crystal, Inc., 171 F. Supp. 293, 299 (S.D.N.Y. 1953).

50 Triangle Publications, frc. v. Rohrlich, 167 F.2d 969, 977 (2d Cir. 1948).

- Note, 41 Connin LQ. 515,518 (1956). Sec ako the criticion by Brown, supra note 52, at 1200, of the thesis advanoed by Callmam in He Who Reaps Bhere He Has Not Sown: Unjart Exidiment in the Law of Unfair Competition, 55 HARv. L. REv. 595 (1942).

61 Although the dilution advocates have primarily emphasioed the need to protect coined and fanciful names, Callmann asserts that the theory would also protect very strong" names. 3 Caumass;, op. cit. supra note 1, at 1644 n.6 (Supp. 1961). Derenberg favors the application of the theory in the "extraordinary cases [of] family names such as "Tiffany:"." Derenberg, spra note 58, at 458. But query whether this view will necessarily prevail under the tatutes. See the statutes supra note 58 and ako the judicial attitude torard personal names, spra note 28.

2 See note 58 supra.

63 Esquire, Inc. v. Esquire Slipper MfE, 243 F.2d 540 (Ist Cir. 1957); HMH Publishing Co. v. Playboy Records, Inc, 161 F. Supp. 540 (X.D. Hl. 1958); Libby, Mctieil \& Libby v. Libby, 103 F. Supp. 968 (D. Mass. 1952); Food Fair Stores, Inc. v. Food Fair, Inc. 8 ? F. Supp. 455 (D. Mass. 1948); Skil Corp v. Bamet, 337 Mass. 485, 150 N.E.2d 551 (1958). 
case has yet arisen under the statutes in which a different result would obtain under the common law sponsorship doctrine. 64 Nevertheless, on the assumption that the statutes create greater rights to very distinctive names, the English language will not be significantly depleted. By definition, the theory will not extend any privileges over words already diluted by usage in the common language. 65

In evaluating the economic implications of the dilution doctrine, two factors should be carefully weighed and balanced. First, the extensive protection proposed by the dilution advocates could increase and solidify whatever market powers are already created by the confusion doctrine. Of course, the monopolistic consequences, whatever their proportions, will be indirectly produced since the additional protection would be oniy against non-competitors. Second, the policy favoring the new doctrine depends upon the extent to which it is desirable to protect a businessman's good will. The confusion doctrine safeguards the reputation of a firm against imitators whose businesses are closely related enough to cause a likelihood of mistaken association. While further protection of good will may be desirable, that desirability should be shown to depend upon social and economic considerations and not upon the bare assertion that a business has a "property interest" to be preserved.66 As one writer has observed, in this field the property notion obscures issues and invites circular reasoning: "It purports to base legal protection upon economic value, when, as a matter of actual fact, the economic value of a [trade name] depends upon the extent to which it will be legally protected." 67

\section{$\mathrm{V}$}

The indiscriminate use of the term "monopoly" may be criticized. In its exclusive-right sense, the term has been employed to suggest potential dangers to the English language. In view of the limited rights granted and the resources of the language, this suggestion appears to be a thinly veiled ad terrorem argument that has only obscured other issues. With its economic meaning, however, the cry of "monopoly" has at least removed any lingering illusion that courts or writers can reason in terms of trade name concepts divorced from social and economic facts. The differentiation encouraged by the judicial trade name doctrine does create some insulation from the full force of competitive pressures. Despite the market effects of the common law doctrine,

${ }^{64} \mathrm{See}$, e.g., cases cited supra note 63. For an excellent review of the antidilution statute cases, see Derenberg, supra note 58, at 448-61. But see that author's observation on Skil Corp. v. Barnet, supra note 63, in Trade Regulation, 34 N.Y.U.L. REv. 846, 850 n.175 (1959).

${ }^{65}$ See Esquire, Inc. v. Esquire Slipper Mfg., 243 F.2d 540, 543, (1st Cir. 1957), 36 N.C.L. REV. 105 (1957).

66 See Cohen, Transcendental Nonsense and the Functional Approach, 35 Colum. L. REv. 809, 814-17 (1935).

6.7 Cohen, supra note 66, at 815 . 
there has been almost universal approval of protection within the immediate competitive market. While this protection is certainly the most likely to have monopolistic effects, the policy against consumer deception has been accepted as controlling and will justify even the confusion of sponsorship doctrine. But the case for the new departure embodied in the dilution statutes is more difficult. As the common law doctrine stands, the good will of a business and the persuasive value of a trade name are protected within the limits set by the confusion doctrine. Increased protection would tend to reinforce existing market powers. On the assumption that competition should be encouraged when there is no danger of consumer deception, the burden of persuasion should rest upon the advocates of the new theory to demonstrate that increased protection is truly desirable. This approach will, it is hoped, at least provoke economic research that will afford law makers reliable guidance. 